\title{
Evaluation of crop management options for replanting of coconut plantations devastated by lethal yellowing disease in Ghana
}

\author{
E. Andoh-Mensah ${ }^{1}$, X. Bonneau ${ }^{2}$, J. Ollivier ${ }^{2}$, B. N. Nuertey ${ }^{1}$ and S. K. Dery ${ }^{1}$
}

\begin{abstract}
Evaluation of four coconut management options was carried out from May 1999 to May 2004 in the coconut belt of the Western and Central Regions of Ghana for replanting of coconut plantations devastated by the Cape St Paul Wilt Disease of Ghana. Coconut hybrid identified for the replanting was MYD x VTT. On fertile soils just intercropping of inter-rows with food crops proved appropriate for managing the coconut hybrid successfully. On low fertile soils however, fertilization was required in addition to intercropping for proper management of the hybrid. Where intercrops were fertilized the coconut palms benefited from the residual effect. While Pueraria phaseoloides did not have any visible impact, Cassia siamea was antagonistic to growth and development of the young coconut hybrid. Fertilized intercropping was more profitable especially on low fertile soils.
\end{abstract}

Key words: Replanting, intercropping, mineral fertilization, young coconut hybrid.

${ }^{1}$ Coconut Research Programme, Oil Palm Research Institute, Box 245, Sekondi, Ghana.

${ }^{2}$ Department of Tree Crops, CIRAD-CP, Montpellier, France. 


\section{Introduction}

The most important crop along the coastal belt of Ghana is undoubtedly the coconut palm. It is estimated that at least $90 \%$ of Ghana's coconut is grown in the coastal areas (Dery et al., 1997). In these areas, coconut is the major source of livelihood and employment. It provides food, drink, fuel wood, edible oil, fibre, animal feed and materials for shelter (Ofori and NkansahPoku, 1997).

A lethal yellowing disease of coconut, known locally as Cape St Paul Wilt Disease (CSPWD) due to its first observance at Cape St Paul in the Volta Region in 1932 (Westwood, 1953), has affected a large area of coconut plantings (mainly West African Tall) in the two major coconut growing regions of Ghana: Western and Central regions (Dery et al., 1997). Currently, the disease is being contained however; the area already devastated about 11,000 hectares as at 2001 (Anonymous, 2002) needs to be replanted with tolerant or resistant varieties.

A project feasibility study in 1997 by a consultant from CIRAD (Centre for International Co-operation on Agricultural Research and Development) identified the coastal zone between Cape Coast in the Central Region and Axim in the Western Region for a replanting programme (Dery et al., 1999). In this zone, coconut plantations, which were under optimal ecological conditions and were the main source of income for the local populations, have been partially or totally destroyed by the disease. Malayan Yellow Dwarf cross Vanuatu Tall (MYD x VTT) coconut hybrid was identified for the replanting. The coconut hybrid has good agronomic characters. Also, observations made for the past 8 years in several MYD x VTT adaptive plots scattered in the disease affected areas have shown that, for the time being, the CSPWD did not spread in this material. However, definitive conclusion needs more years of observation to be drawn. For successful management of the coconut hybrid, crop management options involving mineral fertilization were recommended to the Coconut
Sector Development Project (CSDP) for implementation of the replanting programme. To be able to assess these crop management options, field trials were initiated alongside the replanting programme.

This paper evaluates the various crop management options recommended for replanting of coconut plantations devastated by the CSPWD in Ghana.

\section{Materials and methods}

The trial was carried out from May 1999 to May 2004 at 5 different sites comprising of 3 seashore and 2 inland locations.

The seashore locations were:

- Princess Town (flat and sandy terrain at about $500 \mathrm{~m}$ away from seashore).

- Anlo (slightly sloppy sandy beach along the seashore).

- Ankwanda (narrow stretch of sandy soil between the seashore and a lagoon).

The inland locations were:

- Nyamebekyere (sloppy terrain with gravely and shallow soil).

- Eduma (valley bottom with colluvial and alluvial soils).

These locations stretch between Cape Coast in the Central Region and Axim in the Western Region (see map). All the sites were previously occupied by the West African Tall coconut variety before devastation by the CSPWD. MYD x VTT coconut hybrid was used to establish the trial. Planting was done at $8.5 \mathrm{~m}$ triangular spacing. Four treatments of coconut management options were assessed: $\mathrm{A}=$ Farmer's own upkeep without mineral fertilization (control), B = Mineral fertilization and inter-row slashing but no intercropping, $\mathrm{C}=$ Mineral fertilization with inter-row planted with creeping legume at inland locations or tree legume at seashore locations and $\mathrm{D}=$ Mineral fertilization with inter-row occupied by fertilized intercrops. The 4 treatments were randomly assigned to 4 distinct plots of mean 
size 0.3 ha at each of the 5 sites to obtain a multi - locational design with 5 replicates. Averagely, the plots contained 40 coconut palms comprising of 18 useful and 22 border palms. A total of 3.1 $\mathrm{kg}$ urea, $2.7 \mathrm{~kg}$ single superphosphate (SSP), 5.5 $\mathrm{kg}$ muriate of potash (MOP) and $2.5 \mathrm{~kg}$ kieserite were applied per palm in treatments B, C and D according to the schedule in Table 1.

Table 1. Fertilizer application schedule from 2000 to 2003 in the replanting trial

\begin{tabular}{lccccccc}
\hline $\begin{array}{l}\text { Fertilizer } \\
(\mathrm{kg} / \mathrm{palm})\end{array}$ & $\begin{array}{c}\text { June } \\
2000\end{array}$ & $\begin{array}{c}\text { Oct. } \\
2000\end{array}$ & $\begin{array}{c}\text { May } \\
2001\end{array}$ & $\begin{array}{c}\text { Nov. } \\
2001\end{array}$ & $\begin{array}{c}\text { May } \\
2002\end{array}$ & $\begin{array}{c}\text { Nov. } \\
2002\end{array}$ & $\begin{array}{c}\text { July } \\
2003\end{array}$ \\
\hline Urea & 0.2 & 0.3 & 0.4 & 0.4 & 0.6 & 0.6 & 0.6 \\
SSP & 0.2 & 0.3 & 0.5 & 0.5 & 0.5 & 0.5 & $0.2^{\mathrm{a}}$ \\
MOP & 0.5 & 0.5 & 0.7 & 0.8 & 1.0 & 1.0 & 1.0 \\
& & & & & & & \\
Kieserite & 0.5 & 0.2 & 0.3 & 0.3 & 0.4 & 0.4 & 0.4 \\
\hline
\end{tabular}

Treatments A and D were intercropped with the same food crops determined by the farmer. Food crops in treatment A were managed by the farmer but $\mathrm{D}$ was research-managed. Maize and cassava were the main inter-crops (Table 2). At the seashore locations, treatment $\mathrm{C}$ were interplanted with Cassia siamea (Princess Town) and Acacia mangium (Anlo and Ankwanda) and at inland locations they were inter-planted with Pueraria phaseoloides. At Eduma however, the Pueraria phaseoloides did not establish properly due to its suppression by Panicum spp. Cassia siamea and Acacia mangium were established in the middle of the coconut inter-rows in 2 rows. Planting was done at $3 \mathrm{~m}$ between the 2 rows and $2 \mathrm{~m}$ along the rows. Leaf samples were taken annually in April/May from coconut palms for analysis before fertilizer application. Frond numbers 4 or 9 or 14 were sampled according to the age of the young coconut palms. Soil samples were also taken in September 2003 for analysis. Leaf emission and collar girth were determined at six monthly intervals. Collar girth was measured at the ground level. Palms were inspected for inflorescence emergence and those with emerged inflorescence were recorded. Nut count was carried out in May 2004 in the bunch of leaf rank 14. The number obtained was multiplied by 12 months to estimate annual nut load per palm. Anlo and Ankwanda sites were terminated prematurely in May 2002 due to strong pressure of Oryctes attack on coconut and direct seaspray which affected both coconut and intercrops. Nevertheless, the trial continued at Princess Town, Nyamebekyere and Eduma.

\section{Results}

\section{Leaf analysis}

Leaf $\mathrm{K}, \mathrm{Cl}, \mathrm{P}$ and $\mathrm{N}$ contents averaged over 4 years were higher in the fertilized plots $\mathrm{B}, \mathrm{C}$ and $\mathrm{D}$ relative to the control treatment $\mathrm{A}$. Leaf $\mathrm{K}$ in the fertilized plots was more than the control by $25.6 \%$ at Nyamebekyere, $69.2 \%$ at Eduma, and a whooping $253.4 \%$ at Princess Town (Table 3). Leaf $\mathrm{Cl}$ in the fertilized plots was only $6 \%$ higher at Eduma but $88.7 \%$ and $107.1 \%$ higher at Princess Town and Nyamebekyere respectively compared to the control. Leaf $\mathrm{P}$ content in the fertilized palms was more than the control just by $8.8 \%$ at Eduma, $10.8 \%$ at Princess Town but $53.8 \%$ at Nyamebekere. Leaf $\mathrm{N}$ level in the fertilized treatments was higher than the control by only 2.6\% at Princess Town, $7.4 \%$ at Eduma but $20.1 \%$ at Nyamebekyere. Except at Nyamebekyere, leaf $\mathrm{Mg}$ relative to the control was lower in the fertilized plots: $18.7 \%$ and $32.1 \%$ lower at Eduma and Princess Town respectively. At Nyamebekyere, however, leaf $\mathrm{Mg}$ in the fertilized palms was $49.3 \%$ higher than the control. The response of leaf nutrients to mineral fertilization was clear and strong at Nyamebekyere and also remarkable in some cases (leaf $\mathrm{K}$ and $\mathrm{Cl}$ ) at Princess Town but weak at Eduma except for leaf $\mathrm{K}$ content which was $69.2 \%$ higher than the control.

\section{Soil analysis}

Soils at Princess Town, Nyamebekyere and Eduma sites had $\mathrm{pH}$ ranging from 5.1 - 6.1 in the top soil, low organic matter content except at Princess Town (2.2\%) and sandy to relatively loamy texture. The sites had good soil $\mathrm{N}$ reserves, unsatisfactory $\mathrm{P}$ levels, low $\mathrm{K}$ content (a bit better at Eduma), satisfactory Mg levels 
except at Nyamebekyere, and weak CEC except at Eduma (Table 4). Generally, Eduma had relatively more favourable soil fertility for growth of young coconut palms than Princess Town and even more, Nyamebekyere, where all the indicators showed very poor soil fertility which was reflected in the poor nutrient status of unfertilized young coconut palms of treatment A at the site.

\section{Growth of coconut palms}

Tables 5 and 6 indicate remarkable growth of fertilized palms over the control in terms of collar girth and leaf emission at Nyamebekyere and Princess Town but not at Eduma. At Nyamebekyere, the collar girth of control palms in treatment A from November 2000 to May 2004 increased just 3.4 times compared to a mean of 8.3 in the fertilized palms of treatments B, C and $\mathrm{D}$. Total leaf emission over the same period relative to the control was $76 \%$ greater in the fertilized palms. The collar girth of control palms at Princess Town enlarged 4.2 times from November 2000 to 2003 as against a mean of 7.1 for fertilized treatments B and D. Total leaf emission over the same period was $36.3 \%$ more for the fertilized treatments $\mathrm{B}$ and $\mathrm{D}$ relative to the control. In treatment $\mathrm{C}$ at Princess Town, collar girth and total leaf emission of fertilized palms as at November $2003(84.2 \mathrm{~cm}$ and 20.2 fronds) was comparable only to the control palms (73.2 $\mathrm{cm}$ and 23.7 fronds). At Eduma, collar girth of control palms increased 6.7 times from November 2000 to May 2004 comparing very well with the collar girth of fertilized palms which enlarged 6.5 times over the same period. Total leaf emission in the control: 42.3 fronds was also remarkable considering mean leaf emission of 40.3 fronds in the fertilized palms.

\section{Inflorescence emergence and nut load}

Five years after planting, control palms in treatment A did not record any inflorescence emergence at Nyamebekyere and Princess Town but at Eduma there was $100 \%$ flowering (Table 7). In the fertilized treatment $\mathrm{B}, \mathrm{C}$ and $\mathrm{D}$ mean inflorescence emergence was $93.8 \%$ at Eduma, $59.3 \%$ at Nyamebekyere (with $81.8 \%$ in treatment D) and 56.7\% at Princess Town (with
$80 \%$ in treatment D). In treatment $\mathrm{C}$ at Princess Town, there were no flowering palms just like the control. Nut load followed a similar pattern as the inflorescence emergence (Table 7). The control palms at Eduma recorded an outstanding annual nut load of 132 nuts/palm as against nothing for the control palms at Princess Town and Nyamebekyere which did not have any inflorescence emergence. Mean annual load in the fertilized palms was 33.8 nuts/palm at Nyamebekyere (with 48 nuts/palm in treatment D), 41 nuts/palm at Princess Town (with 58 nuts/palm in treatment D) and 62.3 nuts/palm at Eduma (with 132 nuts/palm in treatment D).

\section{Food crop intercropping}

Inter-rows of treatments $\mathrm{A}$ and $\mathrm{D}$ at Eduma, Princess Town and Nyamebekyere were intercropped with maize in year 2 (2001) (Table 2). However, it was only at Eduma that the maize was successfully harvested. At Princess Town and Nyamebekyere, prolonged moisture stress due to unexpected drought just before ear and tassel initiation led to crop failure. Eduma and Nyamebekyere were again intercropped with maize in year 3 (2002) but the maize at Nyamebekyere was destroyed prematurely by wild antelopes. Princess Town and Nyamebekyere were respectively intercropped in year 4 (2003) and year 5 (2004) with cassava though in restricted inter-rows. At Eduma, it was not possible to intercrop in 2003 after only two cycles of maize due to early canopy closure. Relative to treatment A input costs for cassava intercrop in treatment D at Nyamebekyere and Princess Town were respectively 7.7 and 6.0 times higher; tuber yields were 4.7 and 1.6 times higher; profitability 4.1 and 1.4 times more and work remuneration per man-day were 3.6 and 1.2 times higher (Table 8). Labour requirement for cassava intercrop at Nyamebekyere was 31 man-days in treatment D as against 27 in treatment A. At Princess Town it was 39 man-days in treatment $\mathrm{D}$ compared to 33 in treatment A. At Eduma where maize intercrop was successfully harvested mean input cost in treatment D compared to treatment A was 9.4 higher; grain yield was 1.8 times 
Table 2. Food cropping cycles at Princess Town, Nyamebekyere and Eduma (2001 to 2004)

\begin{tabular}{|lcccc|}
\hline \multicolumn{5}{c}{ YEAR/ MONTHS } \\
\hline & 2001 & 2002 & 2003 & 2004 \\
\hline & J F M A M J & J F M A M J & J F M A M J & J F M A M J \\
& J A S O N D & J A S O N D & J A S O N D & J A S O N D \\
\hline Princess Town & -Maize- & ----- & ----- Cassava ---------- & \\
\hline Nyamebekyere & -Maize- & -Maize* & - & ------- Cassava ----- \\
\hline Eduma & -Maize- & -Maize- & & -- \\
\hline
\end{tabular}

*Maize was destroyed prematurely by antelopes

Table 3. Leaf N, P, K, Mg and Cl at Nyamebekyere, Princess Town and Eduma averaged over 4-years (May 2001 to 2004)

\begin{tabular}{|cccccccc|}
\hline \multirow{2}{*}{ Nyamebekyere } & Treatment & N \% & P & K \% & Mg \% & Cl \% \\
& Fertilized & B, C \& D & 1.694 & 0.100 & 1.832 & 0.215 & 0.845 \\
\hline \multirow{2}{*}{ Princess Town } & Control & A & 1.815 & 0.102 & 0.504 & 0.377 & 0.468 \\
& Fertilized & B, C \& D & 1.863 & 0.113 & 1.781 & 0.256 & 0.883 \\
\hline \multirow{2}{*}{ Eduma } & Control & A & 1.831 & 0.113 & 0.634 & 0.412 & 1.070 \\
& Fertilized & B, C \& D & 1.966 & 0.123 & 1.073 & 0.335 & 1.006 \\
\hline \multirow{2}{*}{ Mean } & Control & A & 1.686 & 0.093 & 0.714 & 0.311 & 0.649 \\
& Fertilized & B, C \& D & 1.841 & 0.112 & 1.562 & 0.269 & 0.911 \\
\hline
\end{tabular}

Table 4. Some chemical properties of soils at the sites of the trial in September 2003

\begin{tabular}{|l|c|c|c|c|c|c|}
\hline \multirow{2}{*}{ Site } & $\mathrm{cm}$ & $\%$ & $\mathrm{mg} / \mathrm{kg}$ & \multicolumn{2}{|c|}{------- meq/ 100 g -------- } \\
\cline { 2 - 7 } & Soil depth & Total N & $\begin{array}{c}\text { Avail. P } \\
\text { (Olsen D. }\end{array}$ & $\begin{array}{c}\mathrm{K} \\
\text { exch. }\end{array}$ & $\begin{array}{c}\text { Mg } \\
\text { exch. }\end{array}$ & CEC \\
\hline Princess Town & $0-20$ & 0.89 & 17.0 & 0.05 & 0.62 & 2.54 \\
& $20-40$ & 0.55 & 10.0 & 0.04 & 0.23 & 1.81 \\
Nyamebekyere & $0-20$ & 0.67 & 8.5 & 0.07 & 0.17 & 2.36 \\
& $20-40$ & 0.43 & 8.0 & 0.04 & 0.09 & 2.33 \\
Eduma & $0-20$ & 0.92 & 10.0 & 0.11 & 1.18 & 4.45 \\
& $20-40$ & 0.49 & 6.5 & 0.05 & 0.89 & 3.31 \\
\hline
\end{tabular}


Table 5. Collar girth (cm) of coconut palms from 2000 to 2004 at Princess, Nyamebekyere and Eduma

\begin{tabular}{|c|c|c|c|c|c|c|c|c|c|}
\hline Site & Plot & $\begin{array}{l}\text { Nov. } \\
2000\end{array}$ & $\begin{array}{l}\text { April } \\
2001\end{array}$ & $\begin{array}{l}\text { Nov. } \\
2001\end{array}$ & $\begin{array}{l}\text { May } \\
2002\end{array}$ & $\begin{array}{l}\text { Oct. } \\
2002\end{array}$ & $\begin{array}{l}\text { May } \\
2003\end{array}$ & $\begin{array}{l}\text { Nov. } \\
2003\end{array}$ & $\begin{array}{l}\text { May } \\
2004\end{array}$ \\
\hline $\begin{array}{l}\text { Princess Town } \\
\text { Mean of B \& D }\end{array}$ & $\begin{array}{l}\text { A } \\
\text { B } \\
\text { C } \\
\text { D }\end{array}$ & $\begin{array}{l}17.4 \\
15.0 \\
15.5 \\
18.0 \\
\mathbf{1 6 . 5}\end{array}$ & $\begin{array}{l}19.0 \\
30.9 \\
16.1 \\
25.4 \\
\mathbf{2 8 . 2}\end{array}$ & $\begin{array}{l}31.1 \\
48.8 \\
28.4 \\
38.7 \\
\mathbf{4 3 . 8}\end{array}$ & $\begin{array}{l}32.4 \\
70.3 \\
38.9 \\
58.6 \\
\mathbf{6 4 . 5}\end{array}$ & $\begin{array}{l}46.0 \\
88.2 \\
45.9 \\
83.2 \\
\mathbf{8 5 . 7} \\
\end{array}$ & $\begin{array}{c}59.9 \\
108.4 \\
60.9 \\
113.4 \\
\mathbf{1 1 0 . 9}\end{array}$ & $\begin{array}{c}73.2 \\
116.9 \\
84.2 \\
118.3 \\
\mathbf{1 1 7 . 6}\end{array}$ & $\begin{array}{l}-(1) \\
- \\
- \\
- \\
-\end{array}$ \\
\hline Nyamebekyere & $\begin{array}{l}\text { A } \\
\text { B } \\
\text { C } \\
\text { D }\end{array}$ & $\begin{array}{l}14.9 \\
15.6 \\
13.2 \\
16.5 \\
\mathbf{1 5 . 1}\end{array}$ & $\begin{array}{l}15.1 \\
21.3 \\
18.9 \\
17.4 \\
\mathbf{1 9 . 2}\end{array}$ & $\begin{array}{l}22.4 \\
35.4 \\
34.2 \\
36.2 \\
\mathbf{3 5 . 3}\end{array}$ & $\begin{array}{l}22.9 \\
53.5 \\
52.5 \\
56.7 \\
\mathbf{5 4 . 2}\end{array}$ & $\begin{array}{l}31.5 \\
81.0 \\
79.4 \\
85.7 \\
\mathbf{8 2 . 0}\end{array}$ & $\begin{array}{c}32.2 \\
108.1 \\
107.9 \\
104.8 \\
\mathbf{1 0 6 . 9}\end{array}$ & $\begin{array}{l}42.8 \\
122.5 \\
122.3 \\
118.0 \\
\mathbf{1 2 0 . 9}\end{array}$ & $\begin{array}{c}51.1 \\
126.4 \\
126.7 \\
121.9 \\
\mathbf{1 2 5 . 0}\end{array}$ \\
\hline Mean of $B, C \& D$ & $\begin{array}{l}\text { A } \\
\text { B } \\
\text { C } \\
\text { D }\end{array}$ & $\begin{array}{l}21.6 \\
18.3 \\
19.3 \\
24.7 \\
\mathbf{2 0 . 8}\end{array}$ & $\begin{array}{l}23.7 \\
21.4 \\
19.7 \\
27.8 \\
\mathbf{2 3 . 0}\end{array}$ & $\begin{array}{l}64.3 \\
50.9 \\
48.3 \\
89.9 \\
\mathbf{6 3 . 0}\end{array}$ & $\begin{array}{c}79.6 \\
67.4 \\
63.5 \\
100.6 \\
\mathbf{7 7 . 2}\end{array}$ & $\begin{array}{c}109.4 \\
100.3 \\
98.7 \\
120.9 \\
\mathbf{1 0 6 . 6}\end{array}$ & $\begin{array}{l}132.3 \\
117.8 \\
116.4 \\
144.2 \\
\mathbf{1 2 6 . 1}\end{array}$ & $\begin{array}{l}141.4 \\
126.9 \\
122.5 \\
153.6 \\
134.3\end{array}$ & $\begin{array}{l}144.4 \\
127.7 \\
124.6 \\
155.9 \\
\mathbf{1 3 6 . 1}\end{array}$ \\
\hline
\end{tabular}

(1) No observation recorded due to fire damage in March 2004

Table 6. Leaf emission of coconut palms at Princess Town, Nyamebekyere and Eduma over a 4-year period

\begin{tabular}{|c|c|c|c|c|c|c|c|c|c|}
\hline Site & Plot & $\begin{array}{c}\text { Nov } 00 \\
\text { to } \\
\text { April } 01\end{array}$ & $\begin{array}{c}\text { April } 01 \\
\text { to } \\
\text { Nov } 01\end{array}$ & $\begin{array}{l}\text { Nov } 01 \\
\text { to } \\
\text { May } 02\end{array}$ & $\begin{array}{c}\text { May } 02 \\
\text { to } \\
\text { Oct } 02\end{array}$ & $\begin{array}{c}\text { Oct } 02 \\
\text { to } \\
\text { May } 03\end{array}$ & $\begin{array}{l}\text { May } 03 \\
\text { to } \\
\text { Nov } 03\end{array}$ & $\begin{array}{l}\text { Nov } 03 \\
\text { to } \\
\text { May } 04\end{array}$ & Total \\
\hline $\begin{array}{l}\text { Princess Town } \\
\text { Mean of B \& D }\end{array}$ & $\begin{array}{l}\text { A } \\
\text { B } \\
\text { C } \\
\text { D }\end{array}$ & $\begin{array}{l}1.9 \\
3.5 \\
1.1 \\
2.7 \\
\mathbf{3 . 1}\end{array}$ & $\begin{array}{l}4.3 \\
4.4 \\
3.3 \\
4.7 \\
4.6\end{array}$ & $\begin{array}{l}3.4 \\
4.4 \\
2.8 \\
4.4 \\
4.4\end{array}$ & $\begin{array}{l}3.7 \\
4.9 \\
4.1 \\
4.6 \\
\mathbf{4 . 8}\end{array}$ & $\begin{array}{l}4.8 \\
6.6 \\
4.9 \\
7.1 \\
6.9\end{array}$ & $\begin{array}{l}5.6 \\
7.6 \\
4.0 \\
9.3 \\
\mathbf{8 . 5}\end{array}$ & $\begin{array}{l}-(1) \\
- \\
- \\
- \\
-\end{array}$ & $\begin{array}{l}23.7 \\
31.4 \\
20.2 \\
32.8 \\
\mathbf{3 2 . 3}\end{array}$ \\
\hline $\begin{array}{l}\text { Nyamebekyere } \\
\text { Mean of B, C \& D }\end{array}$ & $\begin{array}{l}\text { A } \\
\text { B } \\
\text { C } \\
\text { D }\end{array}$ & $\begin{array}{l}1.2 \\
2.3 \\
1.9 \\
1.6 \\
\mathbf{1 . 9}\end{array}$ & $\begin{array}{l}2.8 \\
4.0 \\
3.5 \\
4.0 \\
\mathbf{3 . 8}\end{array}$ & $\begin{array}{l}2.7 \\
4.1 \\
4.3 \\
4.5 \\
4.3\end{array}$ & $\begin{array}{l}2.5 \\
4.3 \\
4.1 \\
4.4 \\
\mathbf{4 . 3}\end{array}$ & $\begin{array}{l}3.3 \\
6.4 \\
6.6 \\
6.3 \\
6.4\end{array}$ & $\begin{array}{l}2.8 \\
6.5 \\
7.0 \\
7.3 \\
6.9\end{array}$ & $\begin{array}{l}3.9 \\
6.2 \\
6.4 \\
6.1 \\
6.2\end{array}$ & $\begin{array}{l}19.2 \\
33.8 \\
33.8 \\
34.2 \\
\mathbf{3 3 . 8}\end{array}$ \\
\hline $\begin{array}{l}\text { Eduma } \\
\text { Mean of B, C \& D }\end{array}$ & $\begin{array}{l}\text { A } \\
\text { B } \\
\text { C } \\
\text { D }\end{array}$ & $\begin{array}{l}2.2 \\
1.3 \\
1.4 \\
2.2 \\
\mathbf{1 . 6}\end{array}$ & $\begin{array}{l}5.8 \\
5.8 \\
6.0 \\
6.6 \\
\mathbf{6 . 1}\end{array}$ & $\begin{array}{l}4.8 \\
3.9 \\
3.8 \\
5.8 \\
4.5\end{array}$ & $\begin{array}{l}6.1 \\
6.0 \\
5.9 \\
7.6 \\
6.5\end{array}$ & $\begin{array}{l}7.5 \\
5.8 \\
6.9 \\
8.0 \\
6.9\end{array}$ & $\begin{array}{l}8.5 \\
8.6 \\
8.3 \\
8.3 \\
\mathbf{8 . 4}\end{array}$ & $\begin{array}{l}7.4 \\
5.6 \\
5.6 \\
7.8 \\
\mathbf{6 . 3}\end{array}$ & $\begin{array}{l}42.3 \\
37.0 \\
37.9 \\
46.3 \\
\mathbf{4 0 . 3}\end{array}$ \\
\hline
\end{tabular}

(1) No observation due to fire damage in March 2004 
Table 7. Inflorescence emergence and nut load at Nyamebekyere, Princess and Eduma in May 2004

\begin{tabular}{|c|c|c|c|c|c|c|}
\hline \multirow[b]{2}{*}{ Treatment } & \multicolumn{2}{|c|}{ Nyamebekyere } & \multicolumn{2}{|c|}{ Eduma } & \multicolumn{2}{|c|}{ Princess Town } \\
\hline & $\begin{array}{c}\% \\
\text { flowering }\end{array}$ & $\begin{array}{l}\text { Nut load/ } \\
\text { palm/year }\end{array}$ & $\begin{array}{c}\% \\
\text { flowering }\end{array}$ & $\begin{array}{l}\text { Nut load/ } \\
\text { palm/year }\end{array}$ & $\begin{array}{c}\% \\
\text { flowering }\end{array}$ & $\begin{array}{l}\text { Nut load/ } \\
\text { palm/year }\end{array}$ \\
\hline A & 0.0 & - & 100.0 & 132 & 0.0 & - \\
\hline B & 54.5 & 24 & 100.0 & 22 & 33.3 & 24 \\
\hline $\mathrm{C}$ & 41.7 & 28 & 88.2 & 33 & 0.0 & - \\
\hline $\mathrm{D}$ & 81.8 & 48 & 93.3 & 132 & 80.0 & 58 \\
\hline $\begin{array}{l}\text { Mean of } \\
\text { B, C \& D }\end{array}$ & 59.3 & 33.3 & 93.8 & 62.3 & $56.7^{*}$ & $41 *$ \\
\hline
\end{tabular}

*Mean of B \& D

Table 8. Cost and benefit analysis of intercropping activities in treatments A and D

\begin{tabular}{|c|c|c|c|c|c|c|}
\hline \multicolumn{7}{|c|}{ Nyamebekyere: Cassava intercrop in 2004} \\
\hline Treatment & $\begin{array}{l}\text { Input } \\
\text { cost } \\
(\$)\end{array}$ & $\begin{array}{l}\text { Number of } \\
\text { man-days }\end{array}$ & $\begin{array}{l}\text { Qty of product } \\
\text { harvested } \\
(\mathrm{Kg})\end{array}$ & $\begin{array}{l}\text { Market value } \\
\text { of product } \\
(\$)\end{array}$ & $\begin{array}{c}\text { Profit } \\
\text { Margin (\$) }\end{array}$ & $\begin{array}{l}\text { Work remuneration } \\
\text { per man-day }(\$)\end{array}$ \\
\hline $\mathrm{A}$ & 3.33 & 27 & 320 & 23.44 & 20.11 & 0.75 \\
\hline $\mathrm{D}$ & 25.56 & 31 & 1,488 & 109.00 & 83.44 & 2.69 \\
\hline \multicolumn{7}{|c|}{ Princess Town: Cassava intercrop in 2003} \\
\hline Treatment & $\begin{array}{l}\text { Input } \\
\text { cost } \\
(\$)\end{array}$ & $\begin{array}{l}\text { Number of } \\
\text { man-days }\end{array}$ & $\begin{array}{l}\text { Qty of product } \\
\text { harvested } \\
(\mathrm{Kg})\end{array}$ & $\begin{array}{l}\text { Market value } \\
\text { of product } \\
(\$)\end{array}$ & $\begin{array}{c}\text { Profit } \\
\text { Margin (\$) }\end{array}$ & $\begin{array}{c}\text { Work remuneration } \\
\text { per man-day }(\$)\end{array}$ \\
\hline $\mathrm{A}$ & 4.44 & 33 & 1,920 & 120.27 & 115.82 & 3.51 \\
\hline $\mathrm{D}$ & 26.67 & 39 & 3,096 & 189.01 & 162.34 & 4.16 \\
\hline \multicolumn{7}{|c|}{ Eduma: Maize intercrop in 2002} \\
\hline Treatment & $\begin{array}{l}\text { Input } \\
\text { cost } \\
(\$)\end{array}$ & $\begin{array}{c}\text { Number of man- } \\
\text { days }\end{array}$ & $\begin{array}{l}\text { Qty of product } \\
\text { harvested } \\
(\mathrm{Kg})\end{array}$ & $\begin{array}{l}\text { Market value } \\
\text { of product } \\
(\$)\end{array}$ & $\begin{array}{c}\text { Profit } \\
\text { Margin (\$) }\end{array}$ & $\begin{array}{l}\text { Work remuneration } \\
\text { per man-day }(\$)\end{array}$ \\
\hline $\mathrm{A}$ & 1.11 & 31 & 627.3 & 69.7 & 68.59 & 2.21 \\
\hline $\mathrm{D}$ & 16.89 & 38 & $1,114.8$ & 123.87 & 106.98 & 2.81 \\
\hline \multicolumn{7}{|c|}{ Nyamebekyere: Maize intercrop in 2001} \\
\hline Treatment & $\begin{array}{l}\text { Input } \\
\text { cost } \\
(\$)\end{array}$ & $\begin{array}{c}\text { Number of man- } \\
\text { days }\end{array}$ & $\begin{array}{l}\text { Qty of product } \\
\text { harvested } \\
(\mathrm{Kg})\end{array}$ & $\begin{array}{l}\text { Market value } \\
\text { of product } \\
(\$)\end{array}$ & $\begin{array}{c}\text { Profit } \\
\text { Margin (\$) }\end{array}$ & $\begin{array}{c}\text { Work remuneration } \\
\text { per man-day }(\$)\end{array}$ \\
\hline $\mathrm{A}$ & 7.00 & 17 & - & - & -7.00 & -0.41 \\
\hline $\mathrm{D}$ & 9.56 & 18 & 5.0 & 0.55 & -.9 .01 & -0.50 \\
\hline \multicolumn{7}{|c|}{ Princess Town: Maize intercrop in 2001} \\
\hline Treatment & $\begin{array}{c}\text { Input } \\
\text { cost } \\
(\$) \\
\end{array}$ & $\begin{array}{l}\text { Number of man- } \\
\text { days }\end{array}$ & $\begin{array}{l}\text { Qty of product } \\
\text { harvested } \\
(\mathrm{Kg})\end{array}$ & $\begin{array}{l}\text { Market value } \\
\text { of product } \\
(\$)\end{array}$ & $\begin{array}{c}\text { Profit } \\
\text { Margin (\$) }\end{array}$ & $\begin{array}{l}\text { Work remuneration } \\
\text { per man-day }(\$)\end{array}$ \\
\hline $\mathrm{A}$ & 3.78 & 10 & 5.3 & 0.56 & -3.22 & -0.32 \\
\hline $\mathrm{D}$ & 7.00 & 17 & 10.4 & 1.11 & -5.89 & -0.35 \\
\hline \multicolumn{7}{|c|}{ Eduma: Maize intercrop in 2001} \\
\hline Treatment & $\begin{array}{l}\text { Input } \\
\text { cost } \\
(\$)\end{array}$ & $\begin{array}{l}\text { Number of man- } \\
\text { days }\end{array}$ & $\begin{array}{l}\text { Qty of product } \\
\text { harvested } \\
(\mathrm{Kg})\end{array}$ & $\begin{array}{l}\text { Market value } \\
\text { of product } \\
(\$)\end{array}$ & $\begin{array}{l}\text { Profit } \\
\text { Margin } \\
(\$)\end{array}$ & $\begin{array}{l}\text { Work remuneration } \\
\text { per man-day }(\$)\end{array}$ \\
\hline $\mathrm{A}$ & 1.11 & 30 & 194.5 & 21.6 & 20.5 & 0.68 \\
\hline $\mathrm{D}$ & 3.89 & 33 & 327.5 & 36.4 & 32.5 & 0.98 \\
\hline
\end{tabular}


greater; profitability was 1.6 times more and work remuneration per man-day was 1.3 times higher. Mean labour requirement for maize intercrop was 35.5 man-days in treatment $\mathrm{D}$ as against 30.5 in treatment $\mathrm{A}$.

\section{Discussion}

\section{Leaf and soil analysis}

The clear and strong response of leaf nutrients to mineral fertilization at Nyamebekyere and also remarkable response in some cases (leaf $\mathrm{K}$ and $\mathrm{Cl}$ ) at Princess Town and the generally weak response observed at Eduma could be attributed to differences in soil fertility. According to Wehrmann (1976) the level of response of plants to fertilizer treatment depends on the inherent nutritional content of the unfertilized soil. Results of soil analysis revealed that in general, Eduma had a more favourable soil fertility status than Princess Town and even more at Nyamebekyere. Princess Town was most deficient in exchangeable $\mathrm{K}(0.05 \mathrm{meq} / 100 \mathrm{~g}$ in the top soil) hence the whooping $253.4 \%$ increase in leaf $\mathrm{K}$.

The relatively high levels of leaf $\mathrm{Mg}$ observed in the control at Eduma and Princess Town compared to the fertilized palms could be attributed to $\mathrm{K}: \mathrm{Mg}$ antagonism (Bonneau et al., 2002) since exchangeable $\mathrm{Mg}$ at the 2 sites were already at satisfactory levels (mean of 0.9 meq/100g soil). At Nyamebekyere where the contradiction occurred (higher content of leaf $\mathrm{Mg}$ in fertilized palms than in the control), soil analysis indicated low exchangeable $\mathrm{Mg}(0.17$ $\mathrm{meq} / 100 \mathrm{~g}$ ) at the site.

\section{Growth, inflorescence emergence and nut load of coconut palms}

The outstanding growth of coconut palms at Nyamebekyere in treatments B, C and D and at Princess Town in treatments $\mathrm{B}$ and $\mathrm{D}$ might be due to good assimilation of increased levels of nutrients observed in the palms as a result of fertilizer application. However, for inflorescence emergence and nut production among the fertilized palms, treatment $\mathrm{D}$ which was intercropped in addition to being fertilized performed more remarkably than treatments B and $\mathrm{C}$ which were only fertilized without intercropping. For instance, inflorescence emergence in treatments $\mathrm{B}, \mathrm{C}$ and $\mathrm{D}$ at Nyamebekyere were $54.5 \%, 41.7 \%$ and $81.8 \%$ and annual nut production per palm were 24,28 and 48 respectively. Also, at Princess Town inflorescence emergence in treatments B and D were $33.3 \%$ and $80 \%$ and annual nut production per palm were 24 and 58 respectively. Intercropping helped to ensure better maintenance thereby providing clean environment for the young coconut palms (Reynolds, 1988; Bonneau and Sugarianto, 1999). Since the intercrops were fertilized the coconut palms certainly, benefited from the residual effect (Reynolds, 1988; Ollivier et al., 1994). At Eduma, growth and inflorescence emergence of coconut palms in the control treatment A and fertilized treatments B, C and D compared very well. However, only treatments $\mathrm{A}$ and $\mathrm{D}$ were outstanding in nut production with a mean load of 132 nuts per palm per year as against 22 for treatment $\mathrm{B}$ and 33 for treatment $\mathrm{C}$. This could be attributed again to intercropping activities in treatments A and D. Food intercropping was more important as growth and yield factor than fertilization at Eduma. This was because intercropping was more effective at controlling Panicum maximum; the most aggressive and dominant weed at this site. Therefore, coconut palms in the intercropped plots benefited maximally from fertilizers applied or inherent soil fertility and other available resources required for growth since competition from the weed was minimized (Reynolds, 1988). The tremendous performance of the control palms was not surprising as Eduma site which had relatively fertile soil, favourable for growth of young coconut palms than Princess Town and Nyamebekyere. The control palms at Nyamebekyere and Princess Town did not record any inflorescence emergence 5 years after planting. This was due to poor growth as a result of infertile soils at the sites. This suggests that intercropping alone without fertilization is not sufficient for 


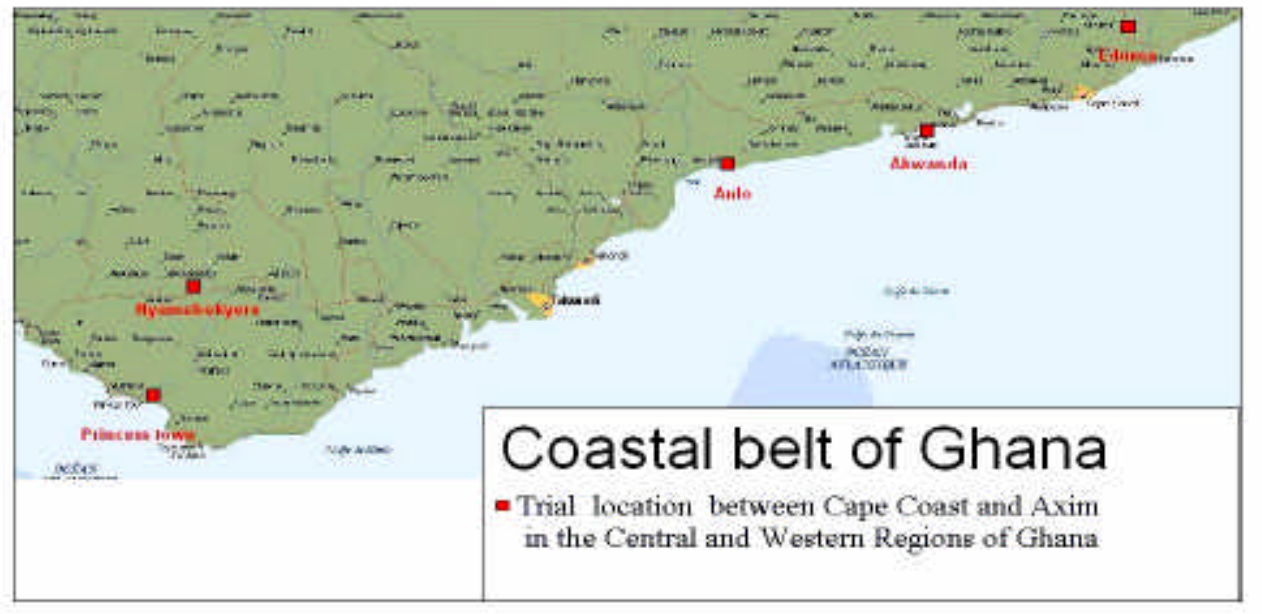

managing the coconut hybrid on low fertile soils. The poor performance of coconut palms in treatment $\mathrm{C}$ at Princess Town might be attributed to possible allelopathy from Cassia siamea planted in the inter-rows (John, 2001) or competition between the coconut palm and the legume tree for growth resources which was perhaps, antagonistic to the coconut palm. For instance, leaf analysis at Princess Town 36 months after commencing fertilizer application indicated for treatment $\mathrm{C}$ the lowest leaf $\mathrm{P}(0.092$ $\%)$ but highest leaf $\mathrm{K}(1.76 \%)$. This could be attributed to the fact that legume plants compete keenly for $\mathrm{P}$ which is vital for nodulation (Graham and Rosas, 1979; Kang et al., 1986; Israel, 1987). For leaf P of $0.092 \%$ which was quite below the reference level of $0.13 \%$ (Magat, 2003), leaf K was unlikely to be fully assimilated hence the accumulation. The planting of Cassia siamea was meant to study the possibility of restoring fertility of sandy soils along the seashore through legume tree planting. Besides, the technique was to provide fuel wood for farmers. The first pruning carried out in August 2002 provided fuel wood measuring $3.5 \mathrm{~m}^{3}$ for the farmer and foliage which was applied as mulch to the coconut. At Nyamebekyere, where the inter-rows of treatment $\mathrm{C}$ were established with Pueraria phaseoloides there was no visible influence on the growth of coconut palms.

\section{Food crop intercropping}

Cassava and maize intercrops in treatment D were research-managed therefore improved practices including planting at recommended spacing, regular weed management and fertilizer application were adopted. Intercrops in treatment A were farmer-managed with minimal weed maintenance and without any fertilizer application. Consequently, input cost for intercropping in treatment $\mathrm{D}$ was relatively high: 6-10 times more than in treatment $\mathrm{A}$. Labour requirement was also more in treatment D: 31-39 man days than in treatment A: 27-33 man days. The relatively high input cost and labour requirement for intercropping activities in treatment D generated more cassava and maize yield leading to more profits and more remuneration per man day than the farmer's practice in treatment $A$. The comparatively high response of cassava intercrop to fertilization at Nyamebekyere could be explained by the low fertility of inherent soil at 
the site (Wehrmann, 1976). This resulted in a greater profit (4.1 times at Nyamebekyere compared to 1.4 times at Princess Town relative to control treatment A) and higher remuneration per man day (3.6 times at Nyamebekyere compared to 1.2 times at Princess Town).

\section{Incidence of lethal yellowing disease}

The MYD x VTT coconut hybrid did not suffer any lethal yellowing during the trial period. Monitoring is still on-going. In an earlier work with the same hybrid, mortality due to lethal yellowing disease was only $0.9 \%$ after 8 years of observation. Even that, no disease foci was formed around the infections. This reinforces the belief that MYD $x$ VTT has some level of tolerance to lethal yellowing disease (Dery et al., 2005).

\section{Conclusion and recommendation}

Intercropping and fertilization were found to be necessary for proper management of the MYD $x$ VTT coconut hybrid to ensure optimum growth and yield. On fertile soils just intercropping of inter-rows with food crops proved appropriate for managing the coconut hybrid successfully. On low fertile soils however, fertilization was required in addition to intercropping for proper management of the hybrid. Maintenance of food intercrops helped to provide clean environment for the young coconut palms thereby enabling the palms to benefit maximally from fertilizers applied or inherent soil fertility and other available resources required for growth. Where intercrops were fertilized the coconut palms benefited from the residual effect. While Pueraria phaseoloides did not have any visible impact, Cassia siamea was antagonistic to growth and development of the young coconut hybrid. Fertilized intercropping was more profitable especially on low fertile soils.

Besides determining appropriate cultural options for managing the MYD x VTT coconut hybrid for replanting the Cape St Paul Wilt Devastated Zone, it is very important to develop suitable coconut - based cropping systems for both replanting and expansion of the coconut industry in Ghana beyond the traditional coastal frontiers where the disease is prevalent. A suitable cropping system should be able to provide an insurance against total crop failure in case of tolerance/resistance breakdown and also alternative sources of income on sustainable basis.

\section{Acknowledgement}

The authors wish to acknowledge that French Development Agency (AFD) financed this study under the Coconut Sector Development Project with Ghana Rubber Estates Limited as the project operator. They also wish to express their gratitude to the data collection team for this work particularly Mr. Kenneth Atta-Peters and Richard Nkrumah of the Coconut Research Programme, Sekondi.

\section{References}

Anonymous, 2002. CSIR-Oil Palm Research Institute. Annual Report - 2001.

Bonneau, X. and Sugarianto, J. 1999. Intercropping with young hybrid coconut palms in climatically marginal areas. Plant. Rech. Dévelop. 6(1): 13 - 29.

Bonneau, X., Dery, S.K. and Andoh-Mensah, E. 2002. Agronomist Mission Report to the Coconut Sector Development Project; $21^{\text {st }}$ April to $5^{\text {th }}$ May 2002. CIRAD-CP, Doc. CP-SIC 1497, Montpellier, France.

Dery, S.K., N'Cho, Y.P., Sangare, A. and Arkhurst, E.D. 1997. Cape Saint Paul Wilt disease: Resistance screening and prospects for rehabilitating the coconut industry in Ghana, pp. 147-152. In: Proceedings of an International Workshop on Lethal Yellowing-like Disease of Coconut, S.J. Eden-Green and F. Ofori (Eds.). Elimina, Ghana. November 1995. Chatman, United Kingdom, Natural Resources Institute.

Dery, S.K., Philippe, R. and Calvez, C.H. 1999. Coconut Sector Development Project: Report on Applied Research Programme 
in Agronomy and Crop Protection to the operator of the Project (GREL), May 1999, pp. 26-28.

Dery, S.K., Arthur, R., Philippe, R., Nuertey, B.N., Nkansah-Poku, J., Owusu-Nipah, J. and Andoh-Mensah, E. 2005. On-farm evaluation of the coconut hybrid, Malayan Yellow Dwarf x Vanuatu Tall for tolerance to the lethal yellowing disease of coconut in Ghana. Cord 21(1): 50-60.

Graham, P.H., and Rosas, J.C. 1979. Phosphorus fertilization and symbiotic nitrogen fixation in common bean. Agron. J. 71: 925-926.

Israel, D.W. 1987. Investigation of the role of phosphorus in symbiotic nitrogen fixation. Plant Physio. 84: 835-840.

John, J. and Nair, A.M. 2001. Allelopathy - a cause of concern in coconut based home gardens of Kerala. Indian Cocon. J. 31(10): 11-12.

Kang, B.T., Wilson, G.F. and Lawson, T.L. 1986. Alley cropping: A stable alternative to shifting cultivation. International Institute of Tropical Agriculture (IITA), Ibadan, Nigeria.

Magat, S.S. 2003. Coconut leaf nutrient levels of bearing dwarf varieties and physiological critical and adequacy levels in crop nutrition management. Cord 19(2): 1-10.
Ofori, F. and Nkansah-Poku, J. 1997. Cape St Paul Wilt Disease of coconut in Ghana: History of its occurrence and spread, pp. 27-32. In: Proceedings of an International Workshop on Lethal Yellowing-like Disease of Coconut, S.J. Eden-Green and F. Ofori (Eds.). Elimina, Ghana. November 1995. Chatman, United Kingdom, Natural Resources Institute, U.K.

Ollivier J., Daniel, C. and Braconnier, S. 1994. Food crop intercropping with young coconut palms, examples in Vanuatu. Oléagineux 49(3): 92-107.

Reynolds, S.C. 1988. Advantages and disadvantages of intercropping coconut. In: Pasture and Cattle under Coconut. FAO Pasture Production and Protection. Paper 91, Rome.

Wehrmann, J. 1976. Possibilities and limits of Intensive fertilization. In: Plant Research and Development. Institute of Scientific Co-operation, Germany, Vol. 3, pp. 101122.

Westwood, D. 1953. Coconut diseases, Keta, Gold Coast. Ghana Farmer 2(1). 